\title{
The development of the research mission in marine biology stations
}

\author{
K. R. Benson \\ Department of Medical History and Ethics, SB-20, University of Washington; Seattle, \\ WA 98195, USA
}

\section{INTRODUCTION}

Because the centennial celebration of the Biologische Anstalt Helgoland corresponds with the beginning of the 1992-93 academic year, perhaps it will be appropriate to note several other important events in the development of the research mission in American biology that occurred during the same academic year one hundred years ago, and that have a bearing on our story. First, as a part of his visit to the Stazione Zoologica in 1892, the American biologist Bashford Dean travelled to Helgoland and wrote of his favourable impressions in two articles, one published in the American Naturalist and one in the Report of the Smithsonian Institution (Dean, 1893, 1894). Second, C. O. Whitman, the first director of the Marine Biological Laboratory in Woods Hole, took the initial steps toward offering advanced instruction and research opportunities at the MBL in 1892, calling for the establishment of an "American marine biological observatory" in an article he published in Popular Science Monthly (Whitman, 1893). Finally, 1892 marked the establishment of the first American marine biology station on the west coast of the United States, Stanford University's Hopkins Seaside Laboratory (later renamed Hopkins Marine Station), Helgoland's "twin" celebrant this year. This latter event is of particular interest, because one of the participants in that first year at Pacific Grove was William Emerson Ritter, who was to found and direct, a decade later, the marine station that eventually became the Scripps Institution of Oceanography (known at its inception in 1903 as the marine laboratory of the Marine Biological Association of San Diego, then as the Scripps Institution for Biological Research in 1912, and finally given its present name in 1925).

But why this "sudden" and apparently widespread national interest in marine biology in general, and research in marine science in particular, along the coastlines of the United States? And is there a relationship between these American developments and the longer-standing interest in marine biology and research in Europe? My remarks in this paper are intended to address both sets of questions and, I hope, illustrate the unique character of developments in marine biology in North America and the critical role that European research stations, such as the Biologische Anstalt Helgoland, played in influencing the direction of these American developments.

Historians of science have already stressed and documented the importance of German laboratory science for late nineteenth-century developments in biology, espe- 
cially through a number of chapters published recently by William Coleman and Frederic L. Holmes in a book titled, "The Investigative Enterprise" (Coleman \& Holmes, 1988). Eric Mills has demonstrated superbly the critical German contributions to biological oceanography, especially in his excellent book detailing the history of the important Kiel programme in oceanography (Mills, 1989). But what is not as well-known is the seminal role that European marine stations played in the development of marine biology and the elaboration of a research ideal for similar laboratories in the United States, particularly in the years between the founding of the Stazione Zoologica in 1872 and the beginning of the American involvement in oceanographic laboratories in 1930 (Benson, $1988 \mathrm{a}$ ). I am not emphasizing the influence on the United States just because I am an American and I have worked extensively in this area; instead, it is evident to me that critical developments enabling American biology to attain quickly to world-class status by the early twentieth century came from a variety of European sources.

\section{EARLY SEASIDE STATIONS IN EUROPE AND THE UNITED STATES}

When Helgoland was established as a marine station in 1892, there were already over twenty marine stations in Europe that specialized in research. Of course, the most famous of these stations for fundamental questions in biology - especially those stemming from Ernst Haeckel's conceptual claims for morphology - was Anton Dohrn's Stazione Zoologica in Naples. Additionally, fundamental questions and innovative approaches toward understanding the open ocean were asked and developed at places like Kiel, Plymouth, and, some years later, Helgoland. While several of these marine stations included some instruction or organized the teaching of courses in marine science, the overwhelming emphasis was upon research. After all, this was the "sine qua non" of German science.

The situation in marine biology was not the same in the United States. Despite an equally long legacy involving studies beside the sea - the first American marine station, Agassiz's Penikese laboratory, opened in 1873, one year after Naples - the designed use of these laboratories by the sea was much different in the New World. Because America completely lacked any tradition in advanced science education and because it was also woefully deficient in the teaching of science in secondary schools, Louis Agassiz's experiment near Woods Hole was addressed to remedy a serious educational problem in his adopted homeland. As a result, Penikese and its successor stations at Salem (1876), Annisquam (1881), and Woods Hole (1888), all located near each other in the environs of Cape Cod (Massachusetts), were intended to cater for an audience of school teachers, not university students or researchers (Benson, $1988 \mathrm{~b}$ ).

The deplorable state of American science began to change, albeit slowly, toward the adoption of research in biology after Johns Hopkins University was opened in 1876 with the specific goal of offering to American students opportunities in the sciences that were available at that time only in Europe. By 1883, an editorial in Science claimed that the United States then had a "small band of men" dedicated to the scientific advancement of their country by importing the "German ideal" of research in science (Anonymous, 1883). One of these men was William Keith Brooks, an original member of the biology faculty at Johns Hopkins and the founder of America's first marine research station, the Chesapeake Zoological Laboratory (CZL) in 1878 (Benson, 1987, Maienschein, 1991). 
Although Brooks's only previous experience at a marine station was one summer at Penikese and later at the Newport laboratory, where Agassiz's son Alexander had his own independent research station, he was well-versed in the morphological literature produced from German laboratories and from Dohrn's station. Brooks's entire programme at the itinerant CZL (it moved from place to place, frequently outside of the Chesapeake Bay proper) was designed to duplicate German-style biological research in North America. Obviously, he met with considerable success in his simple laboratory because his first students - the initial products of America's first graduate programme in biology included E. B. Wilson, Thomas Hunt Morgan, Ross G. Harrison, and E. G. Conklin, all of whom worked at Naples and impressed Dohrn and other European biologists with their biological aptitude.

Another source of change in the direction of a research tradition in American biology came from a growing concern with problems in the fisheries industry. When Spencer Fullerton Baird established the U.S. Fish Commission in 1872, initially with his own funds, he immediately began a reconnaissance for a permanent laboratory site for fisheries research. While he did not live to see the opening of the research station of the Fish Commission in 1885, the new station fulfilled his dream and soon became an important centre for research, not just in fisheries, but in all areas of marine biology. The laboratory - located in Woods Hole - was open to advanced students in the biological sciences who were conducting research on marine organisms (Allard, 1990). Because Johns Hopkins, along with Williams, Princeton, and Harvard, supported Baird's plan in 1882 when federal funding was sparse, Brooks's students frequently used the laboratory; in fact, the CZL moved "en masse" to Woods Hole in 1887.

A final important source of change in American biology came from the growing cadre of American-trained students in biology, especially those young students just completing their research at the newly-created research universities like Johns Hopkins, Clark, and Chicago, or at the universities that had recently reformed their science programmes by adopting a research-style graduate programme like Harvard, Yale, Columbia, Michigan, Cornell, and Pennsylvania. Many of these individuals - men and women alike - went to Europe, especially to Naples, known as the "Mecca for biologists" (after C. O. Whitman's published remarks following his year's visit in 1881-82 (Whitman, 1883). A few visited in the 1880 s, but the flow became a veritable flood in the 1890 s and early twentieth-century, as Americans realized the unparalleled advantages of Naples and other laboratories. T. H. Morgan's testimonial in 1896 represents a typical response by these Americans:

"The special advantages for work in Naples are I think, these: Absolute freedom to work on any subject desired, a plentiful and never failing supply of fresh-material and a well-fitted library at hand... Isolated, as we are in America, from much of the newer, current feeling, we are able in Naples, as in no other laboratory in the world, to get in touch with the best modern work" (Morgan, 1896).

\section{RESEARCH IN AMERICAN MARINE BIOLOGY}

All three elements of change - advanced education and research in the sciences at American universities and colleges, the beginnings of research at the laboratory of the U.S. Fish Commission in Woods Hole, and frequent American exposures to European 
marine laboratories - did not immediately lead to the development of research traditions in American marine biology stations. After all, the three bell-weather occurrences for American marine biology I mentioned at the outset of this paper - Dean's visit to Helgoland in 1892, Whitman's beginning of advanced instruction at the MBL in 1892, and the beginnings of Hopkins Marine Station, also in 1892 - all emphasized the component missing from marine stations in the United States, namely research programmes and opportunities. In fact, even as late as the beginning of the twentieth century all the American marine stations existed primarily as summer teaching institutions, specializing in introductory classes in marine botany and zoology for secondary school teachers.

Nevertheless, there were several American biologists who sought to inject the desired and critical research element, the emerging tradition, that began to proliferate among the country's major academic institutions and soon came to characterize all the science in the United States, into the seaside stations. Biologists, especially of the ilk of Whitman and Ritter, were aware of the advantages that accrued from conducting their research projects by the sea. And by the early twentieth century such advantages were not merely "in the future". Using new microscopical equipment and relying upon increasingly sophisticated microscopical methods that they had learned in German biological institutes and at Naples, a few American biologists began to make major contributions to embryology and the growing new field of cytology in the 1880s and 1890s (Benson, 1988 a). E. B. Wilson eventually wrote a widely-acclaimed textbook, "The Cell in Development and Inheritance" in 1896, the first American book in biology that attracted international attention and the text that defined the cytological tradition in embryology (Wilson, 1896). While much of Wilson's research for his influential book was completed during several visits at the Stazione Zoologica in Naples, a healthy contribution to the book came from research he conducted at Woods Hole. Jacques Loeb, who was recruited from a potential career in German biology in 1892 by Whitman (through the auspices of his American friends, Wilson, and Thomas H. Morgan), demonstrated how physiology could be pursued within a marine context, both through his investigations at Woods Hole and Pacific Grove. Other American investigators, who found time to pursue research despite heavy teaching loads during the short summer sessions, also made numerous contributions to systematics and taxonomy through their natural history work in the marine fauna and flora. In short, by the early twentieth century it was clear to many Americans that the country needed to move from an exclusive teaching mission in the marine world to a mission that included research objectives along the ocean's shore.

An additional obstacle that prevented the full implementation of a research agenda in American marine stations, and another distinctive feature that set the American stations apart from European laboratories, was the level and type of funding for marine laboratories in the United States. In the main, all the early American laboratories were completely dependent upon student tuition and fees for their operating expenses and, in some cases, even for capital budgets. Additional monies were sometimes available from wealthy patrons, for example Timothy Hopkins's gift to build the Hopkins Marine Station, or from charitable service organizations, for example the Women's Education Association that supported the early years at Woods Hole. But, the only government funds available for American marine biology came from the modest support of the laboratory of the U.S. Fish Commission - support many biologists coveted - and from some modest support from state governments for teaching the summer classes, as the states of California and 
Washington supplied during the early years of Ritter's station in San Diego and the marine station in Friday Harbor. As a result, it is not too surprising that the American marine stations did not become year-round laboratories until the second decade of the twentieth century, when funding opportunities expanded. This characteristic also explains why the stations were usually housed in extremely modest buildings with minimal scientific equipment and limited allowances for research objectives.

After at least two decades of experience in marine laboratories, therefore, the American marine biology community had not advanced far from the educational beginnings of the stations. To be sure, Americans knew of the potential in their marine stations for research; but they also recognized the practical, but no less real, limitations in their native country. As a result, and paralleling the growth of marine stations in the United States around 1900, there was an ever-increasing migration of Americans to European marine laboratories, especially the Stazione Zoologica. This migration, which reached its peak in the first decade of the twentieth century, marked the implicit recognition of the scientific community in the United States that, for research, Americans still needed to go to Europe. The German research ideal, despite having been transplanted to Johns Hopkins University in 1876, remained largely in its unrealized state in the marine laboratories of the New World.

Perhaps the major turning point to the full incorporation of research within marine biology, or at least on par with the teaching objectives by the sea, was the publication of Charles Kofoid's "The Biological Stations of Europe", which appeared in 1910, almost twenty years after Dean, Whitman, and Ritter called for more research at American marine stations (Kofoid, 1910). Kofoid's sponsor for his fact-finding tour of the European laboratories was the Bureau of Education, the governmental agency which took upon itself the task of improving educational opportunities in the U.S. The commissioner, Elmer Ellsworth Brown, explained his motives in supporting Kofoid:

"Scientific research, ... is an essential part of higher education instruction. ... To promote a better organization of the agencies of pure research in this country, and especially those agencies connected with the graduate schools of our universities, is therefore one of the ends to be sought in the work of this Bureau [of Education]... This monograph is intended to serve a practical purpose, that of furnishing such an account of the European stations as will further the advancement of similar stations in America" (Brown, 1910).

If Brown's statement did not present a clear and articulate endorsement to add a research component to the objectives of American marine stations, Kofoid's rhetoric in his introduction to the book removed all ambiguity:

"The two principal functions which biological stations fulfil and which cannot be equally well fulfilled by any other existing educational agency are those of instruction-elementary, technical, and advanced - and research in the field of pure science and its applications... The research function of a station is its highest one, and at the same time exhibits its greatest scientific and economic value" (Kofoid, 1910, p. 4).

Perhaps unconsciously, Kofoid underscored his bias for research by mentioning the word "research" twice as often in his opening chapter "The Functions of Biological Stations" as he used the combination of either the word "teaching" or "instruction".

Kofoid continued in his report to systematically list all the major marine and freshwater laboratories in Europe, paying special attention to the physical structure including 
the architecture of the building and the engineering of the water systems, of the laboratories and the opportunities for research at each station. Of particular note are his remarks concerning Naples, Kiel, and Helgoland.

In his extensive report on the Stazione in Naples, Kofoid waxed, if not elegant, at least rhetorical:

"Foremost among the biological stations of the world in the extent and completeness of its material equipment and in the wealth of opportunities it offers, inspiring in its history and unparalleled in its growth, unsurpassed in its contributions to biological science, profound in its influence upon the course of developments of modern biology, and powerful in its stimulus to the establishment of biological stations elsewhere, stands the zoological station of Naples, the peer and leader of them all. The station is and always has been, purely and solely, a research institution" (Kofoid, 1910, p. 8).

Kofoid also extolled the virtues of Kiel, again making specific references to research conducted there and noting that the

"Kiel laboratory is famous in the annals of marine exploration as the center from which sprang the quantitative method of study of marine life... Many types of apparatus... have been devised in this laboratory" (Kofoid, 1910, p. 220).

Beginning his comments about Helgoland by emphasizing the relative "youth" of the Biologische Anstalt Helgoland, Kofoid provided the following description:

"The Helgoland Station offers exceptional opportunities for the study of marine plankton, of the natural history of fishes, of marine algae, and of bird migrations. Its remarkably complete outfit of fishing appliances and the lines of investigation in progress by its staff render the station one of the foremost centers in Europe for an insight into the intensive and efficient application of modern scientific methods to the problems of sea fisheries" (Kofoid, 1910, p. 230).

Kofoid's book was not, however, just a rhetorical polemic to support the notion of adding research to American marine biology, for he had his own personal agenda. After all, he served as Ritter's assistant director of the Scripps station in La Jolla and, as a result, had specific motives to argue for more research in marine biology. In addition, he also made a strong argument for governmental funding of science. Of course, this latter suggestion may appear to have been empty and futile, because government sources of support for science in 1910 were virtually nonexistent in the United States. However, what Kofoid was alluding to was money that had become available to the biological sciences from the U.S Fish Commission, the Smithsonian Institution, the U.S. Navy, a variety of state and local public agencies, and the loose association between the federal government and two new major foundations supporting science and higher education at the time, the Rockefeller Foundation and the Carnegie Institution of Washington. Added to these sources were a number of wealthy Americans who had benefited from the economic boom of the early twentieth century, who had become imbued with the value of science for the United States, and who were also interested in supporting science within academic institutions. These individuals included the philanthropists C. R. Crane (Chicago) who gave to the MBL, Timothy Hopkins who provided substantial funds for two separate building phases at Pacific Grove, and the Scripps family who singlehandidly financed and endowed the laboratory in La Jolla. 


\section{CONCLUSION}

While it is beyond the scope of this paper to detail all the immediate results of the new funding for marine stations and biological research in the twentieth century in the United States, I would like to emphasize a few important aspects of it. First, beginning before 1910 but increasing dramatically in the second decade of the twentieth century, the new funding allowed for a rapid capital expansion of the four major marine stations in the United States, the laboratories at Woods Hole, Pacific Grove, La Jolla, and Friday Harbor. For all these stations, this meant that they became equipped for the first time with the substantial buildings and the sufficient equipment that was necessary to enable them to conduct German-style research within the marine setting.

Second, more money was available from American sources to rent tables from Dohrn at Naples. The Carnegie Institution of Washington and the Smithsonian Institution "subscribed" to several tables to augment or replace those rented by Alexander Agassiz, Columbia, and a group of American women (Groeben \& Benson, 1993). This enabled many more American biologists to learn the latest research strategies and methods firsthand. The increase in the support for these tables thus explains the dramatic rise in the number of Americans who travelled to Naples between 1895 and 1910, precisely at the time when opportunities for work in American marine stations were just beginning.

Finally, money from the Rockefeller and Carnegie foundations was also used to send leaders of the American biology community to Europe to examine and to learn from laboratories there, and to bring European marine scientists to the United States. An especially important example of the latter was the Norwegian plankton expert, $\mathrm{H} . \mathrm{H}$. Gran, who visited T. C. Frye at Friday Harbor and H. B. Bigelow in the Gulf of Maine in 1928 , teaching them the latest methods of quantitative plankton research. Gran left a legacy at both places, a legacy that was important for the eventual funding of oceanographic programmes at the University of Washington and the new Woods Hole Oceanographic Institution (WHOI) in 1930 (Benson, 1990).

While these statements have been sketchy and suggestive, rather than thorough and persuasive, they have been intended to provide a cursory glimpse into the different character of early American developments in marine biology, thereby illustrating the critical importance of the European influences for this new tradition by the sea. To recapitulate briefly, American marine biology did not begin as an offshoot of the Stazione Zoologica, but as an attempt to reform science education in the United States. However, as Americans became trained in the biological sciences, they increasingly looked to Europe, especially to Naples, Kiel, Plymouth, and Helgoland for inspiration and direction. Particularly important in this regard was Anton Dohrn, who served as a "spiritual" leader for many of these young Americans. Shortly before he died, he noted the rapid growth of American biology toward world stature, claiming in a letter to E. B. Wilson that he was sure the German spirit of biological research would move to the New World in the near future (Dohrn, 1902). Dohrn's comment to Wilson provides an argument for the claim that the real German roots for American marine biology were established in the years shortly before World War I: here they helped to reorient American marine biology from teaching by the sea to a research mission in the marine environment, thereby equipping American biology to confront the challenges of a changing world in the early twentieth century. 


\section{LITERATURE CITED}

Allard, D. C., 1990. The Fish Commission laboratory and its influence on the founding of the marine biological laboratory. - J. Hist. Biol. 23, 251-270.

Anonymous, 1883. National traits in science. - Science, N. Y. 2, 455-457.

Benson, K. R., 1987. H. Newell Martin, W. K. Brooks, and the reformation of American biology, - Am Zool. 27, 759-771.

Benson, K. R., 1988 a. Review paper: the Naples Stazione Zoologica and its impact on the emergence of American marine biology. - J. Hist. Biol. 21, 331-341.

Benson, K. R., 1988 b. Laboratories on the New England shore: the "somewhat different direction" of American marine biology. - New Engl. Q. 56, 53-78.

Benson, K. R., 1990. H. H. Gran and the development of phytoplankton research on the American West Coast. - Dt. hydrogr. Z. Erg.-H. (Reihe B) 22, 375-377.

Brown, E. E. 1910, Letter of transmittal. In: The biological stations of Europe. By C. A. Kofoid. Government Printing Office, Washington, XI.

Coleman, W. \& Holmes, F. L. (Eds.), 1988. The investigative enterprise: experimental physiology in nineteenth-century medicine. Univ. of California Press, Berkeley, $342 \mathrm{pp}$.

Dean, B., 1893. Notes on marine laboratories in Europe. - Am. Nat. 27, 625-637; 697-707.

Dean, B., 1894. Notes on marine laboratories of Europa. - Rep. Smithson. Inst. 1893, 505-519.

Dohrn, A., 1902. Letter to E. B. Wilson, 10. 5. 1902. Archives, Stazione Zoologica Napoli (unpublished).

Groeben, C. \& Benson, K. R., 1993. Sources in the history of American biology at the archives of the Stazione Zoologica "Anton Dohrn". - Mendel Newsl., New Ser. 2, (Nov. 1992), 5-11.

Kofoid, C. A., 1910. The biological stations of Europe. Government Printing Office, Washington, $360 \mathrm{pp}$.

Maienschein, J., 1991. Transforming traditions in American biology 1880-1915. Johns Hopkins Univ. Press, Baltimore, 366 pp.

Mills, E. L., 1989. Biological oceanography: an early history, 1870-1960. Cornell Univ. Press, Ithaca, $378 \mathrm{pp}$.

Morgan, T. H., 1896. Impressions of the Naples Zoological Station. - Science, N. Y. 3, 16-18.

Whitman, C. O., 1883, The advantage of study at the Naples Zoology Station. - Science, N. Y. $2,94$.

Whitman, C. O., 1893. A marine biological observatory. - Pop. Sci. Mon. 42, 459-471.

Wilson, E. B., 1896. The cell in development and inheritance. Macmillan, New York, 377 pp. 